\title{
Recent development in clinical applications of PD-1 and PD-L1 antibodies for cancer immunotherapy
}

\author{
Bingshan Liur, ${ }^{1,2}$ Yongping Song $2^{2^{*}}$ and Delong Liu ${ }^{2^{*}}$ (D)
}

\begin{abstract}
Antibodies against programmed death (PD) pathway are revolutionizing cancer immunotherapy. Currently five antibodies against PD-1/PD-L1 have been approved. The clinical use of these antibodies is rapidly expanding. Incorporation of PD antibodies into chemotherapy regimens is in active clinical investigations. The combination of pembrolizumab with carboplatin and pemetrexed has been approved for the first line therapy of metastatic non-squamous non-small cell lung cancer. Combination of PD-1/PD-L1 antibodies with small molecule inhibitors such as tyrosine kinase inhibitors and IDO inhibitors are in active clinical trials. This review summarized recent development in clinical trials of PD-1 and PD-L1 antibodies for cancer immunotherapy.
\end{abstract}

\section{Background}

Targeted therapies for cancer with small molecules and monoclonal antibodies (MoAb) have led to significant improvement in the long-term survival of multiple malignancies [1-11]. The discovery of programmed death1 (PD-1) and the ligand 1 (PD-L1) has opened the door to the modern era of cancer immunotherapy $[12,13]$. It is well known now that many tumor cells are able to upregulate the expression of PD-L1 which leads to anergy of cytotoxic T cells upon PD-1 binding to the ligand. Blocking the PD-1 pathway using monoclonal antibodies against PD-1 or PDL1 can therefore revamp the immune response against tumor cells [14]. The development of MoAbs against PD-1 and PD-L1 has led to the fast and fundamental paradigm shift in cancer therapy [15]. The anti-PD drugs are the new form of tumor-site immune modulation therapy through resetting immune reservoir in the tumor microenvironment $[16,17]$. This is fundamentally different from the conventional chemotherapy and radiation that mainly target cancer cells themselves.

PD-L1 expression on the tumor cells and immune cells have become biomarkers that can assist clinical decisions in the choice of treatment strategies [18, 19]. Biomarker assays for PD-L1 are playing bigger roles and

\footnotetext{
*Correspondence: songyongping001@163.com; delong_liu@nymc.edu ${ }^{2}$ Henan Cancer Hospital and the Affiliated Cancer Hospital of Zhengzhou University, 127 Dongming Road, Zhengzhou 450008, China Full list of author information is available at the end of the article
}

are being routinely done nowadays. However, PD-L1 assays can be highly variable, which makes it a clinical challenge to employ the results. In this review, we summarized latest clinical development of PD antibodies and immunohistochemistry (IHC) assays for PD-L1 biomarker expression in clinical practice.

\section{New development in clinical applications of PD-1 and PD-L1 antibodies}

The US Food and Drug Administration (FDA) has approved 5 immune checkpoint blockers in 11 types of advanced malignancies (Table 1 ).

Nivolumab has FDA approved indications for treatment of eight types of advanced malignancies. These malignancies include melanoma, NSCLC (non-small cell lung cancer), classical Hodgkin lymphoma, HNSCC (squamous cell carcinoma of the head and neck), renal cell carcinoma, urothelial carcinoma, hepatocellular carcinoma, and microsatellite instability (MSI)-high or mismatch repair gene (MMR)-deficient colorectal cancer (Table 1) [20-35]. It has been observed that pneumonitis may be associated with responses to PD antibodies [36, 37].

Nivolumab is being explored in more and more cancer types. Twenty patients with platinum-resistant ovarian cancer were treated with nivolumab in a phase II trial. Patients received up to six cycles (four doses per cycle). Twenty nivolumab-treated patients were evaluable at the 
Table 1 Clinical applications of PD-1 and PD-L1 antibodies

\begin{tabular}{lll}
\hline Antibodies & Dosages $^{\text {a }}$ & Indications $^{\text {b }}$ \\
\hline Pembrolizumab & $200 \mathrm{mg}$ over 60 min q3 weeks & $\begin{array}{l}\text { Melanoma, NSCLC, HNSCC, urothelial carcinoma, Hodgkin's lymphoma, } \\
\text { MSI-high cancer, gastric cancer }\end{array}$ \\
& $\begin{array}{l}200 \mathrm{mg} \text { over } 60 \text { min q3 weeks } \\
\text { carboplatin/pemetrexed }\end{array}$ & First line combination therapy for metastatic non-squamous NSCLC \\
Nivolumab & $240 \mathrm{mg}$ over $60 \mathrm{~min}$ q2 weeks & Melanoma, NSCLC, renal cell carcinoma, urothelial carcinoma, \\
& $3 \mathrm{mg} / \mathrm{kg}$ over $60 \mathrm{~min}$ q2 weeks & MSI-high /dMMR CRC, HCC \\
Atezolizumab & $1200 \mathrm{mg}$ over 60 min q3 weeks & Hodgkin's lymphoma, HNSCC \\
Durvalumab & $10 \mathrm{mg} / \mathrm{kg}$ over 60 min q2 weeks & Urothelial carcinoma, NSCLC \\
Avelumab & $10 \mathrm{mg} / \mathrm{kg}$ over $60 \mathrm{~min}$ q2 weeks & Urothelial carcinoma
\end{tabular}

Abbreviations: NSCLC non-small cell lung cancer, HNSCC head/neck squamous cell carcinoma, MSI microsatellite instability; dMMR deficient mismatch repair gene, CRC colorectal cancer, HCC hepatocellular carcinoma, min minute, $q 3 w$ every 3 weeks

${ }^{\mathrm{a}} \mathrm{Ffor}$ pediatric dosing and for combination dosage and schedules, please refer to full prescribing information for each individual agent

${ }^{\mathrm{b}}$ For exact indications, please refer to full prescribing information for each individual agent

time of the report and found to have ORR of $15 \%$. Two of the responding patients had a durable CR (in the $3 \mathrm{mg} / \mathrm{kg}$ cohort). At the termination of the study, the median PFS was 3.5 months and the median overall survival (OS) was 20.0 months. The encouraging results from this pilot study of nivolumab in patients with platinum-resistant ovarian cancer suggest potential benefit of PD-1 antibody for refractory ovarian cancer [38]. Nivolumab is being studied in a phase I trial as a maintenance therapy for patients with high-risk hematological malignancies (NCT02985554). More than 350 trials of nivolumab have been registered on clinicaltrials.gov.

Currently, pembrolizumab has FDA approved indications of seven different types of advanced malignancies. These malignancies include melanoma [39, 40], NSCLC [41-44], HNSCC, urothelial carcinoma, Hodgkin's lymphoma [45], and gastric cancer [46, 47] (Table 1). Among these, FDA approved one indication for any malignancy with high microsatellite instability or mismatch repair gene (MMR) deficiency [48]. However, response to pembrolizumab in a gastric patient with stable MSI and proficient MMR has been observed [49]. Pembrolizumab has also been reported to be active in other highly refractory malignancies, such as Ewing's sarcoma [50]. Recently, pembrolizumab was reported to be active in patients with refractory large cell lymphoma of the mediastinum [51].

Pembrolizumab has been studied in 26 patients with advanced Merkel cell carcinoma who had not received previous systemic therapy [52]. The overall response rate was $56 \%$. The responses were seen in tumors with positive Merkel cell polyomavirus as well as in those with negative viral infections.

Atezolizumab is approved for treatment of advanced NSCLC and urothelial carcinoma [53-61]. The clinical activity of atezolizumab (MPDL3280A) in renal cell carcinoma (RCC) has been evaluated in 70 patients with metastatic RCC [62]. There were 63 with clear cell RCC and 7 with non-clear cell histology. These patients received atezolizumab every 3 weeks. PD-L1 expression was assessed with the Ventana SP142 assay on tumor cells and tumor-infiltrating immune cells (IC). For patients with clear cell RCC, the OS was 28.9 months (95\% CI, 20.0 months to not reach) and PFS was 5.6 months (95\% CI, 3.9 to 8.2 months). The ORR was $15 \%$ (95\% CI, 7 to $26 \%$ ). When the response was correlated with PD-L1 expression on IC cells, it was found that higher response rate was seen in PD-L1 expression ICs (18\% RR in IC1/2/3, 9\% RR in IC0). This study provided data to guide further trials with atezolizumab in RCC.

Durvalumab is approved for treatment of advanced urothelial carcinoma [63, 64]. Recently, the result of PACIFIC study was reported [65]. This was a randomized, placebo-controlled study of consolidation therapy for non-resectable stage III NSCLC after 2 cycles of planned chemoradiotherapy. Durvalumab was given as $10 \mathrm{mg} / \mathrm{kg}$ iv infusion over $30 \mathrm{~min}$ every 2 weeks up to 12 months. The PFS was significantly better for durvalumab (16.8 months, $95 \%$ CI 13 to $18.1 \mathrm{~m}$ ) than that of the placebo arm (5.6 m, 95\% CI, 4.6-7.8 m), $p<0.001)$. Overall survival as the secondary endpoint favored durvalumab, whereas the safety measures were similar in both groups. From this study, durvalumab was found to prolong PFS for approximately 11 months.

Avelumab is approved for treatment of advanced Merkel cell cancer and advanced urothelial carcinoma [66, 67]. In a dose-escalation phase 1a trial, avelumab has demonstrated an acceptable safety profile and early suggestion of activity in patients with advanced solid tumors [68]. A phase Ib dose-expansion cohort of that trial was done in a cohort of patients with advanced, platinum-treated non-small-cell lung cancer (NSCLC) [69]. In this trial, 184 patients were treated with avelumab and followed for a median of 8.8 months. Severe 
adverse events (SAE) occurred in $44 \%$ of the 184 patients. The most common treatment-emerging adverse events (TEAE) among the 184 patients were fatigue $25 \%$, infusion-related reaction (IRR) $21 \%$, and nausea $13 \%$. The ORR was $12 \%$ (95\% CI 8-18), including 1 CR and 21 PR. In addition, 38\% had stable disease. Further study on avelumab for advanced NSCLC appears to be warranted.

\section{Combination studies of PD-1 and PD-L1 antibodies with chemotherapy}

In an attempt to enhance clinical benefits of cancer immunotherapy, PD antibodies are being evaluated in clinical trials in combination with chemotherapeutic agents [70]. The benefit of PD antibody in combination with radiation remains to be determined [71].

Nivolumab in combination with ipilimumab has been shown to improve progression-free survival of and approved for unresectable or metastatic melanoma [72]. A recent update from this trial revealed benefit on prolonged 3-year overall survival [73]. Nivolumab plus ipilimumab combination was studied in an open-label, phase 1, multi-cohort study (CheckMate 012) treatmentnaïve patients with recurrent stage IIIb or stage IV NSCLC [74]. The first-line nivolumab plus ipilimumab was tolerable and showed a high response rate. This study supports further clinical trial of this combination in a phase 3 study.

Nivolumab plus platinum-based doublet chemotherapy (PT-DC) was evaluated for safety and tolerability as first-line therapy in 56 patients with advanced NSCLC [75]. Nivolumab plus PT-DC were given concurrently every 3 weeks for 4 cycles. This was followed by nivolumab alone as maintenance until progression or unacceptable toxicity. SAEs occurred in $45 \%$ of the patients. Seven percent had pneumonitis. AE-related discontinuation rate was reported more with the combination. Similar responses were seen in all dose levels irrelevant of PD-L1 expression. 2 -year OS rate reached $62 \%$ in the nivolumab $5 \mathrm{mg} / \mathrm{kg}$ plus PT-DC group. This may warrant further investigation.

Pembrolizumab was studied in combination with the doublet chemotherapy of carboplatin and pemetrexed in a multicenter randomized phase II study for patients with chemotherapy-naïve stage IIIB/IV non-squamous NSCLC and without EGFR or ALK mutations (KEYNOTE-021) [76]. In this study, PD-L1 tumor proportion score was stratified as $<1 \%$ vs $>/=1 \%$. A total of 123 patients were enrolled in this published report. Among these patients, 60 received pembrolizumab plus chemotherapy (the combination group) and 63 had chemotherapy alone. Four cycles of pembrolizumab $200 \mathrm{mg}$ plus carboplatin area under curve $5 \mathrm{mg} / \mathrm{mL}$ per min and pemetrexed $500 \mathrm{mg} / \mathrm{m} 2$ every 3 weeks were given to all patients. This was followed by pembrolizumab for 24 months and indefinite pemetrexed maintenance therapy versus indefinite pemetrexed maintenance therapy alone. At disease progression, those patients in the pemetrexed alone group were allowed for crossover to receive pembrolizumab. The primary endpoint was objective response rate (ORR). The ORR in the combination group was $55 \%$ (95\% CI 42-68). This was significantly better than that in the pemetrexed alone group $(29 \% ; 18-41)$ $(p=0.0016)$. The incidence of severe treatment-emerging adverse events (TEAEs) was similar, and the most common ones were anemia and neutropenia. This was the first prospective randomized study that showed a benefit of a triplet regimen over doublet chemotherapy. This combination modality has been approved by FDA as the first line treatment for metastatic non-squamous NSCLC (Table 1). The benefit of adding pembrolizumab to platinumdoublet is being confirmed in two ongoing international, randomized, double-blind, phase 3 studies, KEYNOTE189/NCT02578680 and KEYNOTE-407/NCT02775435.

\section{Combination studies of PD-1 and PD-L1 antibodies with other agents}

Bevacizumab was combined with atezolizumab in a trial for metastatic RCC. When intra-tumoral CD8(+) T cells were enumerated and compared, it was found that the $\mathrm{T}$ cells increased in number following combination treatment. Biomarkers were examined in the study. Increase in chemokines was most notable for CX3CL1 (fractalkine) and its receptors. Following bevacizumab and atezolizumab combination treatment, more lymphocytes were seen in tumor tissues. This study suggests that the bevacizumab and atezolizumab combination improves antigen-specific T-cell migration [77].

Durvalumab was studied in a phase Ib trial in combination with osimertinib in NSCLC patients with EGFR activating mutations. The part $\mathrm{A}$ enrolled patients who were pretreated with EGFR tyrosine kinase inhibitors (TKI), and the part B enrolled treatment-naïve NSCLC patients. This combination was terminated for further enrollment due to high incidence of interstitial lung disease (38\%) [78]. In a separate study, durvalumab was evaluated in a phase I trial in combination with gefitinib in treatment-naïve patients with NSCLC [79]. Early results appeared to be encouraging yet higher incidence of grade $3 / 4$ liver enzyme elevation $(40-70 \%)$ was observed. Atezolizumab was also studied in a phase I trial in combination with erlotinib in NSCLC patients with EGFR activating mutations [80]. In this report, 28 patients were included. TEAEs were seen in $50 \%$ of the patients, though no pneumonitis was reported. Early results from combination of EGFR TKIs with immunotherapy revealed higher incidence of TEAEs. Therefore, the combination therapy of EGFR TKI and immunotherapy remains investigational [78]. 
PD-1 antibodies are also being studied in combination with indoximod, an inhibitor of indoleamine 2,3-dioxigenase 1 (IDO1) (NCT03301636) [81]. In a single arm phase 2 study of indoximod in combination with immunotherapy for patients with metastatic melanoma, a large majority of patients received indoximod with pembrolizumab as reported in an interim analysis [82]. Indoximod was given as $1200 \mathrm{mg}$ PO twice daily concurrently with pembrolizumab (3 $\mathrm{mg} / \mathrm{kg}$ q 21 days). The primary endpoint was ORR. In this report, 60 patients received the indoximod/pembrolizumab combination. The ORR was 52\% (CR 8\% + PR 44\%). The combination was well tolerated. GI toxicities, anemia (17\%), and hyperglycemia (17\%) were the most common adverse events. A randomized phase $2 / 3$ study of indoximod in combination with pembrolizumab or nivolumab is ongoing in patients with advanced melanoma (NLG2107, NCT03301636). Other IDO inhibitors are also being evaluated in combination with immunotherapy [81].

\section{Bioassays for PD-L1}

The discovery of targetable oncogenes led to the routine molecular testing for gene mutations, such as those genes encoding epidermal growth factor receptor (EGFR) and BRAF V600E, ALK, the rat osteosarcoma (ROS1), FLT3, and IDH1/2 [41, 83]. More and more companion or complementary diagnostic assays are being approved upon approval of pharmaceutical products. A companion diagnostic assay is defined as a necessary test for the safe and efficacious use of a corresponding drug or biological product, whereas a complementary diagnostic assay is a test that evaluates a biomarker for the companion product to assess the risk/benefit ratio for a subset of patients $[84,85]$. A complementary assay is not deemed essential in decision-making for the companion product. Avelumab was approved without a companion/complementary assay (Table 2).

Evaluation of PD expression on tumor cells and tumor-infiltrating $\mathrm{T}$ cells assists clinical decisions [86-88]. A variety of detection platforms were studied at different levels (protein, mRNA). Four immunohistochemistry (IHC)based assays have been approved by FDA (Table 2). These assays include Dako 22C3, 28-8, and Ventana SP142 and SP263 $[89,90]$. These bioassays have disparate positivity cut-

Table 2 Bioassays for PD-L1 expression

\begin{tabular}{ll}
\hline Antibodies & Bioassays \\
\hline Pembrolizumab & Dako 22C3 \\
Nivolumab & Dako 28-8 \\
Atezolizumab & Ventana SP142 \\
Durvalumab & Ventana SP263 \\
Avelumab & NA \\
\hline
\end{tabular}

NA not applicable off points and scoring systems in different tissue types. Therefore, standardization of clinical decision-making proves to be highly challenging.

Multiple studies have suggested that PD-L1 expression is affected by the specimen size, biopsy location, variable components of tumor and immune microenvironment, and tumor transformation [89]. To use PD-L1 as a predictive biomarker in clinical practice, these factors should be taken into consideration.

There exists a soluble form of PD-L1 (sPD-L1) in the sera of patients [91-94]. It remains unclear whether sPD-L1 level has correlation with clinical response to the checkpoint inhibitor treatment. It has been suggested that high SPD-L1 levels correlate with poor prognosis [95-98]. Liquid biopsy is increasingly used as a substitute of tissue sampling [99]. The value of liquid biopsy results and correlation with response to PD antibodies are uncertain at this time. Further development of multi-parameter biomarker panels is urgently needed.

\section{Conclusion and future directions}

PD antibodies are revolutionizing cancer immunotherapy. The clinical use of PD antibodies is rapidly expanding. It has been shown that treatment history with hypomethylating agents appears to enhance response to PD-1 antibody [45]. Recent reports have shown that pembrolizumab is able to enhance CAR-T cell activity [100, 101]. Incorporation of PD antibodies into chemotherapy regimens is in active clinical investigations. Combination of PD antibodies with small molecule inhibitors such as IDO inhibitors and TKIs may further increase clinical efficacy.

\section{Abbreviations}

HNSCC: Head and neck squamous cell carcinoma; NSCLC: Non-small cell lung cancer; PD: Programmed death; RCC: Renal cell carcinoma; UCC: Urothelial cell carcinoma

\section{Acknowledgements}

This study was partly supported by Henan Cancer Hospital and the affiliated Cancer Hospital of Zhengzhou University.

\section{Funding}

This project was partly supported by the Zhengzhou University training fellowship (BL) and by the National Natural Science Foundation of China (NSFC grant no. 81470287, YPS). BL is a recipient of 2017 CAHON Young Investigator Award (www.cahon.org).

Availability of data and materials

The material supporting the conclusion of this study has been included within the article.

\section{Authors' contributions \\ $\mathrm{DL}$ designed the study. All authors participated in the draft of the manuscript. All authors read and approve the final manuscript.}

Ethics approval and consent to participate

This is not applicable for this study.

Consent for publication

This is not applicable for this study. 


\section{Competing interests}

The authors declare that they have no competing interests.

\section{Publisher's Note}

Springer Nature remains neutral with regard to jurisdictional claims in published maps and institutional affiliations.

\section{Author details}

${ }^{1}$ School of Basic Medical Sciences and the Affiliated Cancer Hospital of Zhengzhou University, Zhengzhou, China. ${ }^{2}$ Henan Cancer Hospital and the Affiliated Cancer Hospital of Zhengzhou University, 127 Dongming Road, Zhengzhou 450008, China.

\section{Received: 17 October 2017 Accepted: 15 November 2017} Published online: 01 December 2017

\section{References}

1. Kantarjian HM, DeAngelo DJ, Stelljes M, Martinelli G, Liedtke M, Stock W, Gokbuget N, O'Brien S, Wang K, Wang T, Paccagnella ML, Sleight B, Vandendries E, Advani AS. Inotuzumab ozogamicin versus standard therapy for acute lymphoblastic leukemia. N Engl J Med. 2016:375(8):740-53.

2. Wang S, Cang S, Liu D. Third-generation inhibitors targeting EGFR T790M mutation in advanced non-small cell lung cancer. J Hematol Oncol. 2016:9:34.

3. Shaw AT, Kim DW, Mehra R, Tan DS, Felip E, Chow LQ, Camidge DR, Vansteenkiste J, Sharma S, De Pas T, Riely GJ, Solomon BJ, Wolf J, Thomas M, Schuler M, Liu G, Santoro A, Lau YY, Goldwasser M, Boral AL, Engelman JA. Ceritinib in ALK-rearranged non-small-cell lung cancer. N Engl J Med. 2014;370(13):1189-97.

4. Shaw AT, Kim DW, Nakagawa K, Seto T, Crino L, Ahn MJ, De Pas T, Besse B, Solomon BJ, Blackhall F, YL W, Thomas M, O'Byrne KJ, Moro-Sibilot D, Camidge DR, Mok T, Hirsh V, Riely GJ, lyer S, Tassell V, Polli A, Wilner KD, Janne PA. Crizotinib versus chemotherapy in advanced ALK-positive lung cancer. N Engl J Med. 2013;368(25):2385-94

5. YL W, Zhou C, Liam CK, Wu G, Liu X, Zhong Z, Lu S, Cheng Y, Han B, Chen L, Huang C, Qin S, Zhu Y, Pan H, Liang H, Li E, Jiang G, How SH, Fernando MC, Zhang Y, Xia F, Zuo Y. First-line erlotinib versus gemcitabine/cisplatin in patients with advanced EGFR mutation-positive non-small-cell lung cancer: analyses from the phase III, randomized, open-label, ENSURE study. Ann Oncol. 2015;26(9):1883-9.

6. Yang JC, Wu YL, Schuler M, Sebastian M, Popat S, Yamamoto N, Zhou C, Hu CP, O'Byrne K, Feng J, Lu S, Huang Y, Geater SL, Lee KY, Tsai CM, Gorbunova V, Hirsh V, Bennouna J, Orlov S, Mok T, Boyer M, Su WC, Lee KH, Kato T, Massey D, Shahidi M, Zazulina V, Sequist LV. Afatinib versus cisplatin-based chemotherapy for EGFR mutation-positive lung adenocarcinoma (LUX-lung 3 and LUX-lung 6): analysis of overall survival data from two randomised, phase 3 trials. Lancet Oncol. 2015;16(2):141-51.

7. Wang S, Song Y, Yan F, Liu D. Mechanisms of resistance to third-generation EGFR tyrosine kinase inhibitors. Front Med. 2016;10(4):383-8.

8. Alexander PB, Wang X-F. Resistance to receptor tyrosine kinase inhibition in cancer: molecular mechanisms and therapeutic strategies. Front Med. 2015;9(2):134-8

9. Kantarjian $\mathrm{H}$, Jabbour $\mathrm{E}$, Topp MS. Blinatumomab for acute lymphoblastic leukemia. N Engl J Med. 2017;376(23):e49.

10. Kantariian H, Stein A, Gokbuget N, Fielding AK, Schuh AC, Ribera JM, Wei A, Dombret H, Foa R, Bassan R, Arslan O, Sanz MA, Bergeron J, Demirkan F, Lech-Maranda E, Rambaldi A, Thomas X, Horst HA, Bruggemann M, Klapper W, Wood BL, Fleishman A, Nagorsen D, Holland C, Zimmerman Z, Topp MS. Blinatumomab versus chemotherapy for advanced acute lymphoblastic leukemia. N Engl J Med. 2017;376(9):836-47.

11. Burger JA, Tedeschi A, Barr PM, Robak T, Owen C, Ghia P, Bairey O, Hillmen P, Bartlett NL, Li J, Simpson D, Grosicki S, Devereux S, McCarthy H, Coutre S, Quach H, Gaidano G, Maslyak Z, Stevens DA, Janssens A, Offner F, Mayer J, O'Dwyer M, Hellmann A, Schuh A, Siddiqi T, Polliack A, Tam CS, Suri D, Cheng $M$, et al. Ibrutinib as initial therapy for patients with chronic lymphocytic leukemia. N Engl J Med. 2015;373(25):2425-37.

12. Dong H, Zhu G, Tamada K, Chen L. B7-H1, a third member of the B7 family, co-stimulates T-cell proliferation and interleukin-10 secretion. Nat Med. 1999:5(12):1365-9.

13. Dong H, Strome SE, Salomao DR, Tamura H, Hirano F, Flies DB, Roche PC, Lu J, Zhu G, Tamada K, Lennon VA, Celis E, Chen L. Tumor-associated B7-H1 promotes T-cell apoptosis: a potential mechanism of immune evasion. Nat Med. 2002:8(8):793-800.

14. Topalian Suzanne L, Drake Charles G, Pardoll Drew M. Immune checkpoint blockade: a common denominator approach to cancer therapy. Cancer Cell. 2015;27(4):450-61.

15. Liu K, Tan S, Chai Y, Chen D, Song H, Zhang CW, Shi Y, Liu J, Tan W, Lyu J, Gao S, Yan J, Qi J, Gao GF. Structural basis of anti-PD-L1 monoclonal antibody avelumab for tumor therapy. Cell Res. 2017;27(1):151-3.

16. Topalian SL, Hodi FS, Brahmer JR, Gettinger SN, Smith DC, McDermott DF, Powderly JD, Carvajal RD, Sosman JA, Atkins MB. Safety, activity, and immune correlates of anti-PD-1 antibody in cancer. N Engl J Med. 2012;366: 2443-54.

17. Brahmer JR, Tykodi SS, Chow LQ, Hwu WJ, Topalian SL, Hwu P, Drake CG, Camacho LH, Kauh J, Odunsi K, Pitot HC, Hamid O, Bhatia S, Martins R, Eaton K, Chen S, Salay TM, Alaparthy S, Grosso JF, Korman AJ, Parker SM, Agrawal S, Goldberg SM, Pardoll DM, Gupta A, Wigginton JM. Safety and activity of anti-PD-L1 antibody in patients with advanced cancer. N Engl J Med. 2012;366(26):2455-65.

18. Daud Al, Wolchok JD, Robert C, Hwu WJ, Weber JS, Ribas A, Hodi FS, Joshua AM, Kefford R, Hersey P, Joseph R, Gangadhar TC, Dronca R, Patnaik A, Zarour H, Roach C, Toland G, Lunceford JK, Li XN, Emancipator K, DolledFilhart M, Kang SP, Ebbinghaus S, Hamid O. Programmed death-ligand 1 expression and response to the anti-programmed death 1 antibody pembrolizumab in melanoma. J Clin Oncol. 2016:34(34):4102-9.

19. Loo K, Daud A. Emerging biomarkers as predictors to anti-PD1/PD-L1 therapies in advanced melanoma. Immunotherapy. 2016:8(7):775-84.

20. Topalian SL, Sznol M, McDermott DF, Kluger HM, Carvajal RD, Sharfman WH, Brahmer JR, Lawrence DP, Atkins MB, Powderly JD, Leming PD, Lipson EJ, Puzanov I, Smith DC, Taube JM, Wigginton JM, Kollia GD, Gupta A, Pardoll DM, Sosman JA, Hodi FS. Survival, durable tumor remission, and long-term safety in patients with advanced melanoma receiving nivolumab. J Clin Oncol. 2014:32(10):1020-30.

21. Weber JS, D'Angelo SP, Minor D, Hodi FS, Gutzmer R, Neyns B, Hoeller C, Khushalani NI, Miller WH Jr, Lao CD, Linette GP, Thomas L, Lorigan P, Grossmann KF, Hassel JC, Maio M, Sznol M, Ascierto PA, Mohr P, Chmielowski B, Bryce A, Svane IM, Grob JJ, Krackhardt AM, Horak C, Lambert A, Yang AS, Larkin J. Nivolumab versus chemotherapy in patients with advanced melanoma who progressed after anti-CTLA-4 treatment (CheckMate 037): a randomised, controlled, open-label, phase 3 trial. Lancet Oncol. 2015;16(4):375-84

22. Robert C, Long GV, Brady B, Dutriaux C, Maio M, Mortier L, Hassel JC, Rutkowski P, McNeil C, Kalinka-Warzocha E, Savage KJ, Hernberg MM, Lebbe C, Charles J, Mihalcioiu C, Chiarion-Sileni V, Mauch C, Cognetti F, Arance A, Schmidt H, Schadendorf D, Gogas H, Lundgren-Eriksson L, Horak C, Sharkey B, Waxman IM, Atkinson V, Ascierto PA. Nivolumab in previously untreated melanoma without BRAF mutation. N Engl J Med. 2015:372(4):320-30

23. Gettinger SN, Horn L, Gandhi L, Spigel DR, Antonia SJ, Rizvi NA, Powderly JD, Heist RS, Carvajal RD, Jackman DM, Sequist LV, Smith DC, Leming P, Carbone DP, Pinder-Schenck MC, Topalian SL, Hodi FS, Sosman JA, Sznol M, McDermott DF, Pardoll DM, Sankar V, Ahlers CM, Salvati M, Wigginton JM, Hellmann MD, Kollia GD, Gupta AK, Brahmer JR. Overall survival and longterm safety of nivolumab (anti-programmed death 1 antibody, BMS-936558, ONO-4538) in patients with previously treated advanced non-small-cell lung cancer. J Clin Oncol. 2015;33(18):2004-12.

24. Brahmer J, Reckamp KL, Baas P, Crino L, Eberhardt WE, Poddubskaya E, Antonia S, Pluzanski A, Vokes EE, Holgado E, Waterhouse D, Ready N, Gainor J Aren Frontera O, Havel L, Steins M, Garassino MC, Aerts JG, Domine M, Paz-Ares L, Reck M, Baudelet C, Harbison CT, Lestini B, Spigel DR. Nivolumab versus docetaxel in advanced squamous-cell non-small-cell lung cancer. N Engl J Med. 2015;373(2):123-35.

25. Rizvi NA, Mazieres J, Planchard D, Stinchcombe TE, Dy GK, Antonia SJ, Horn L, Lena H, Minenza E, Mennecier B, Otterson GA, Campos LT, Gandara DR Levy BP, Nair SG, Zalcman G, Wolf J, Souquet PJ, Baldini E, Cappuzzo F, Chouaid C, Dowlati A, Sanborn R, Lopez-Chavez A, Grohe C, Huber RM, Harbison CT, Baudelet C, Lestini BJ, Ramalingam SS. Activity and safety of nivolumab, an anti-PD-1 immune checkpoint inhibitor, for patients with advanced, refractory squamous non-small-cell lung cancer (CheckMate 063): a phase 2, single-arm trial. Lancet Oncol. 2015;16(3):257-65.

26. Borghaei H, Paz-Ares L, Horn L, Spigel DR, Steins M, Ready NE, Chow LQ Vokes EE, Felip E, Holgado E, Barlesi F, Kohlhaufl M, Arrieta O, Burgio MA, Fayette J, 
Lena H, Poddubskaya E, Gerber DE, Gettinger SN, Rudin CM, Rizvi N, Crino L, Blumenschein GR Jr, Antonia SJ, Dorange C, Harbison CT, Graf Finckenstein F, Brahmer JR. Nivolumab versus docetaxel in advanced nonsquamous nonsmall-cell lung cancer. N Engl J Med. 2015;373(17):1627-39.

27. Motzer RJ, Escudier B, McDermott DF, George S, Hammers HJ, Srinivas S, Tykodi SS, Sosman JA, Procopio G, Plimack ER, Castellano D, Choueiri TK, Gurney H, Donskov F, Bono P, Wagstaff J, Gauler TC, Ueda T, Tomita Y, Schutz FA, Kollmannsberger C, Larkin J, Ravaud A, Simon JS, LA X, Waxman IM, Sharma P, CheckMate I. Nivolumab versus everolimus in advanced renalcell carcinoma. N Engl J Med. 2015;373(19):1803-13.

28. Motzer RJ, Rini BI, McDermott DF, Redman BG, Kuzel TM, Harrison MR, Vaishampayan UN, Drabkin HA, George S, Logan TF, Margolin KA, Plimack ER, Lambert AM, Waxman IM, Hammers HJ. Nivolumab for metastatic renal cell carcinoma: results of a randomized phase II trial. J Clin Oncol. 2015;33(13):1430-7.

29. McDermott DF, Drake CG, Sznol M, Choueiri TK, Powderly JD, Smith DC, Brahmer JR, Carvajal RD, Hammers HJ, Puzanov I, Hodi FS, Kluger HM, Topalian SL, Pardoll DM, Wigginton JM, Kollia GD, Gupta A, McDonald D, Sankar V, Sosman JA, Atkins MB. Survival, durable response, and long-term safety in patients with previously treated advanced renal cell carcinoma receiving nivolumab. J Clin Oncol. 2015;33(18):2013-20.

30. Ansell SM. Nivolumab in the treatment of Hodgkin lymphoma. Clin Cancer Res. 2017:23(7):1623-6.

31. Younes A, Santoro A, Shipp M, Zinzani PL, Timmerman JM, Ansell S, Armand P, Fanale M, Ratanatharathorn V, Kuruvilla J. Nivolumab for classical Hodgkin's lymphoma after failure of both autologous stem-cell transplantation and brentuximab vedotin: a multicentre, multicohort, singlearm phase 2 trial. Lancet Oncol. 2016;17:1283-94.

32. Foran AE, Nadel HR, Lee AF, Savage KJ, Deyell RJ. Nivolumab in the treatment of refractory pediatric Hodgkin lymphoma. J Pediatr Hematol Oncol. 2017;39(5):e263-6.

33. Overman MJ, McDermott R, Leach JL, Lonardi S, Lenz HJ, Morse MA, Desai J, Hill A, Axelson M, Moss RA, Goldberg MV, Cao ZA, Ledeine JM, Maglinte GA, Kopetz S, Andre T. Nivolumab in patients with metastatic DNA mismatch repair-deficient or microsatellite instability-high colorectal cancer (CheckMate 142): an open-label, multicentre, phase 2 study. Lancet Oncol. 2017;18(9):1182-91.

34. Bellmunt J, Powles T, Vogelzang NJ. A review on the evolution of PD-1/PDL1 immunotherapy for bladder cancer: the future is now. Cancer Treat Rev. 2017;54:58-67.

35. Sangro B, Park J-W, Cruz CMD, Anderson J, Lang L, Neely J, Shaw JW, Cheng A-L. A randomized, multicenter, phase 3 study of nivolumab vs sorafenib as first-line treatment in patients (pts) with advanced hepatocellular carcinoma (HCC): CheckMate-459. J Clin Oncol. 2016;34(15_suppl):TPS4147.

36. Khunger M, Rakshit S, Pasupuleti V, Hernandez AV, Mazzone P, Stevenson J, Pennell NA, Velcheti V. Incidence of pneumonitis with use of programmed death 1 and programmed death-ligand 1 inhibitors in nonsmall cell lung cancer: a systematic review and meta-analysis of trials. Chest. 2017:152(2):271-81.

37. De Velasco G, Je Y, Bossé D, Awad MM, Ott PA, Moreira RB, Schutz F, Bellmunt J, Sonpavde GP, Hodi FS, Choueiri TK. Comprehensive metaanalysis of key immune-related adverse events from CTLA-4 and PD-1/PDL1 inhibitors in cancer patients. Cancer Immunol Res. 2017;5(4):312-8.

38. Hamanishi J, Mandai M, Ikeda T, Minami M, Kawaguchi A, Murayama T, Kanai M, Mori Y, Matsumoto S, Chikuma S, Matsumura N, Abiko K, Baba T, Yamaguchi K, Ueda A, Hosoe Y, Morita S, Yokode M, Shimizu A, Honjo T, Konishi I. Safety and antitumor activity of anti-PD-1 antibody, Nivolumab, in patients with platinum-resistant ovarian cancer. J Clin Oncol. 2015; 33(34):4015-22.

39. Tsai K, Daud A. Nivolumab plus ipilimumab in the treatment of advanced melanoma. J Hematol Oncol. 2015;8:123.

40. Hsueh EC, Gorantla KC. Novel melanoma therapy. Exp Hematol Oncol. 2016;5(1):23.

41. Reck M, Rabe KF. Precision diagnosis and treatment for advanced nonsmall-cell lung cancer. N Engl J Med. 2017;377(9):849-61.

42. Reck M, Rodríguez-Abreu D, Robinson AG, Hui R, Csőszi T, Fülöp A, Gottfried M, Peled N, Tafreshi A, Cuffe S, O'Brien M, Rao S, Hotta K, Leiby MA, Lubiniecki GM, Shentu Y, Rangwala R, Brahmer JR. Pembrolizumab versus chemotherapy for PD-L1-positive non-small-cell lung cancer. N Engl J Med. 2016;375(19):1823-33.

43. Dholaria B, Hammond W, Shreders A, Lou Y. Emerging therapeutic agents for lung cancer. J Hematol Oncol. 2016;9:138.
44. Ma W, Gilligan BM, Yuan J, Li T. Current status and perspectives in translational biomarker research for PD-1/PD-L1 immune checkpoint blockade therapy. J Hematol Oncol. 2016;9:47.

45. Falchi L, Sawas A, Deng C, Amengual JE, Colbourn DS, Lichtenstein EA, Khan KA, Schwartz LH, O'Connor OA. High rate of complete responses to immune checkpoint inhibitors in patients with relapsed or refractory Hodgkin lymphoma previously exposed to epigenetic therapy. J Hematol Oncol. 2016:9(1):132.

46. Fuchs CS, Doi T, Jang RW-J, Muro K, Satoh T, Machado M, Sun W, Jalal SI, Shah MA, Metges J-P, Garrido M, Golan T, Mandala M, Wainberg ZA, Catenacci DVT, Bang Y-J, Wang J, Koshiji M, Dalal RP, Yoon HH. KEYNOTE059 cohort 1: efficacy and safety of pembrolizumab (pembro) monotherapy in patients with previously treated advanced gastric cancer. J Clin Oncol. 2017;35(15_suppl):4003.

47. Bang Y-J, Muro K, Fuchs CS, Golan T, Geva R, Hara H, Jalal SI, Borg C, Doi T, Wainberg ZA, Wang J, Koshiji M, Dalal RP, Chung HC. KEYNOTE-059 cohort 2: safety and efficacy of pembrolizumab (pembro) plus 5-fluorouracil (5-FU) and cisplatin for first-line (1L) treatment of advanced gastric cancer. J Clin Oncol. 2017;35(15_suppl):4012.

48. Goel G, Sun W. Advances in the management of gastrointestinal cancers-an upcoming role of immune checkpoint blockade. J Hematol Oncol. 2015;8:86.

49. Chen K-H, Yuan C-T, Tseng L-H, Shun C-T, Yeh K-H. Case report: mismatch repair proficiency and microsatellite stability in gastric cancer may not predict programmed death-1 blockade resistance. J Hematol Oncol. 2016;9(1):29.

50. McCaughan GJB, Fulham MJ, Mahar A, Soper J, Hong AM, Stalley PD, Tattersall MHN, Bhadri VA. Programmed cell death-1 blockade in recurrent disseminated Ewing sarcoma. J Hematol Oncol. 2016;9(1):48.

51. Zinzani PL, Ribrag V, Moskowitz CH, Michot JM, Kuruvilla J, Balakumaran A, Zhang Y, Chlosta S, Shipp MA, Armand P. Safety and tolerability of pembrolizumab in patients with relapsed/refractory primary mediastinal large B-cell lymphoma. Blood. 2017;130(3):267-70.

52. Nghiem PT, Bhatia S, Lipson EJ, Kudchadkar RR, Miller NJ, Annamalai L, Berry S, Chartash EK, Daud A, Fling SP, Friedlander PA, Kluger HM, Kohrt HE, Lundgren L, Margolin K, Mitchell A, Olencki T, Pardoll DM, Reddy SA, Shantha EM, Sharfman WH, Sharon E, Shemanski LR, Shinohara MM, Sunshine JC, Taube JM, Thompson JA, Townson SM, Yearley JH, Topalian SL, et al. PD-1 blockade with Pembrolizumab in advanced Merkel-cell carcinoma. N Engl J Med. 2016;374(26):2542-52.

53. Sidaway P. Bladder cancer: Atezolizumab effective against advanced-stage disease. Nat Rev Urol. 2016;13(5):238.

54. Sidaway P. Urological cancer: atezolizumab effective against advanced disease. Nat Rev Clin Oncol. 2016;13(5):266.

55. Sidaway P. Bladder cancer: Atezolizumab: an alternative to cisplatin? Nat Rev Urol. 2017;14(2):67.

56. Sidaway P. Urological cancer: atezolizumab: an alternative to cisplatin? Nat Rev Clin Oncol. 2017;14(3):139.

57. Balar AV, Galsky MD, Rosenberg JE, Powles T, Petrylak DP, Bellmunt J, Loriot Y, Necchi A, Hoffman-Censits J, Perez-Gracia JL, Dawson NA, van der Heijden MS, Dreicer R, Srinivas S, Retz MM, Joseph RW, Drakaki A, Vaishampayan UN, Sridhar SS, Quinn DI, Duran I, Shaffer DR, Eigl BJ, Grivas PD, Yu EY, Li S, Kadel EE 3rd, Boyd Z, Bourgon R, Hegde PS, et al. Atezolizumab as first-line treatment in cisplatin-ineligible patients with locally advanced and metastatic urothelial carcinoma: a single-arm, multicentre, phase 2 trial. Lancet. 2017;389(10064):67-76.

58. Fehrenbacher L, Spira A, Ballinger M, Kowanetz M, Vansteenkiste J, Mazieres J, Park K, Smith D, Artal-Cortes A, Lewanski C, Braiteh F, Waterkamp D, He P, Zou W, Chen DS, Yi J, Sandler A, Rittmeyer A, Group PS. Atezolizumab versus docetaxel for patients with previously treated non-small-cell lung cancer (POPLAR): a multicentre, open-label, phase 2 randomised controlled trial. Lancet. 2016;387(10030):1837-46.

59. Inman BA, Longo TA, Ramalingam S, Harrison MR. Atezolizumab: a PD-L1blocking antibody for bladder cancer. Clin Cancer Res. 2017;23(8):1886-90.

60. Rittmeyer A, Barlesi F, Waterkamp D, Park K, Ciardiello F, von Pawel J, Gadgeel SM, Hida T, Kowalski DM, Dols MC, Cortinovis DL, Leach J, Polikoff J, Barrios C, Kabbinavar F, Frontera OA, De Marinis F, Turna H, Lee JS, Ballinger M, Kowanetz M, He P, Chen DS, Sandler A, Gandara DR, Group OAKS. Atezolizumab versus docetaxel in patients with previously treated non-small-cell lung cancer (OAK): a phase 3, open-label, multicentre randomised controlled trial. Lancet. 2017;389(10066):255-65.

61. Rosenberg JE, Hoffman-Censits J, Powles T, van der Heijden MS, Balar AV, Necchi A, Dawson N, O'Donnell PH, Balmanoukian A, Loriot Y, Srinivas S, 
Retz MM, Grivas P, Joseph RW, Galsky MD, Fleming MT, Petrylak DP, PerezGracia JL, Burris HA, Castellano D, Canil C, Bellmunt J, Bajorin D, Nickles D, Bourgon R, Frampton GM, Cui N, Mariathasan S, Abidoye O, Fine GD, et al. Atezolizumab in patients with locally advanced and metastatic urothelial carcinoma who have progressed following treatment with platinum-based chemotherapy: a single-arm, multicentre, phase 2 trial. Lancet. 2016; 387(10031):1909-20.

62. McDermott DF, Sosman JA, Sznol M, Massard C, Gordon MS, Hamid O, Powderly JD, Infante JR, Fassò M, Wang W, Zou W, Hegde PS, Fine GD, Powles T. Atezolizumab, an anti-programmed death-ligand 1 antibody, in metastatic renal cell carcinoma: long-term safety, clinical activity, and immune correlates from a phase la study. J Clin Oncol. 2016;34(8):833-42.

63. Massard C, Gordon MS, Sharma S, Rafii S, Wainberg ZA, Luke J, Curiel TJ, Colon-Otero G, Hamid O, Sanborn RE, O'Donnell PH, Drakaki A, Tan W, Kurland JF, Rebelatto MC, Jin X, Blake-Haskins JA, Gupta A, Segal NH. Safety and efficacy of durvalumab (MED|4736), an anti-programmed cell death Ligand-1 immune checkpoint inhibitor, in patients with advanced Urothelial bladder cancer. J Clin Oncol. 2016;34(26):3119-25.

64. Brower V. Anti-PD-L1 inhibitor durvalumab in bladder cancer. Lancet Oncol. 2016;17(7):e275

65. Antonia SJ, Villegas A, Daniel D, Vicente D, Murakami S, Hui R, Yokoi T, Chiappori A, Lee KH, de Wit M, Cho BC, Bourhaba M, Quantin X, Tokito T, Mekhail T, Planchard D, Kim YC, Karapetis CS, Hiret S, Ostoros G, Kubota K, Gray JE, Paz-Ares L, de Castro CJ, Wadsworth C, Melillo G, Jiang H, Huang Y, Dennis PA, Ozguroglu M, et al. Durvalumab after chemoradiotherapy in stage III non-small-cell lung cancer. N Engl J Med. 2017;377 https://doi.org/ 10.1056/NEJMoa1709937.

66. Sidaway P. Skin cancer: avelumab effective against Merkel-cell carcinoma. Nat Rev Clin Oncol. 2016;13(11):652.

67. Kaufman HL, Russell J, Hamid O, Bhatia S, Terheyden P, D'Angelo SP, Shih KC, Lebbe C, Linette GP, Milella M, Brownell I, Lewis KD, Lorch JH, Chin K, Mahnke L, von Heydebreck A, Cuillerot JM, Nghiem P. Avelumab in patients with chemotherapy-refractory metastatic Merkel cell carcinoma: a multicentre, single-group, open-label, phase 2 trial. Lancet Oncol. 2016; 17(10):1374-85.

68. Heery CR, O'Sullivan-Coyne G, Madan RA, Cordes L, Rajan A, Rauckhorst M, Lamping E, Oyelakin I, Marte JL, Lepone LM, Donahue RN, Grenga I, Cuillerot JM, Neuteboom B, Heydebreck AV, Chin K, Schlom J, Gulley JL. Avelumab for metastatic or locally advanced previously treated solid tumours (JAVELIN solid tumor): a phase 1a, multicohort, dose-escalation trial. Lancet Oncol. 2017;18(5):587-98.

69. Gulley JL, Rajan A, Spigel DR, lannotti N, Chandler J, Wong DJL, Leach J, Edenfield WJ, Wang D, Grote HJ, Heydebreck A, Chin K, Cuillerot J-M, Kelly K. Avelumab for patients with previously treated metastatic or recurrent non-small-cell lung cancer (JAVELIN solid tumor): dose-expansion cohort of a multicentre, open-label, phase 1b trial. Lancet Oncol. 18(5):599-610.

70. Alsaab HO, Sau S, Alzhrani R, Tatiparti K, Bhise K, Kashaw SK, lyer AK. PD-1 and PD-L1 checkpoint signaling inhibition for cancer immunotherapy: mechanism, combinations, and clinical outcome. Front Pharmacol. 2017;8:561.

71. Alexander GS, Palmer JD, Tuluc M, Lin J, Dicker AP, Bar-Ad V, Harshyne LA, Louie J, Shaw CM, Hooper DC, Lu B. Immune biomarkers of treatment failure for a patient on a phase I clinical trial of pembrolizumab plus radiotherapy. J Hematol Oncol. 2016;9:96.

72. Postow MA, Chesney J, Pavlick AC, Robert C, Grossmann K, McDermott D, Linette GP, Meyer N, Giguere JK, Agarwala SS. Nivolumab and ipilimumab versus ipilimumab in untreated melanoma. N Engl J Med. 2015;372:2006-17.

73. Wolchok JD, Chiarion-Sileni V, Gonzalez R, Rutkowski P, Grob J-J, Cowey CL, Lao CD, Wagstaff J, Schadendorf D, Ferrucci PF, Smylie M, Dummer R, Hill A, Hogg D, Haanen J, Carlino MS, Bechter O, Maio M, Marquez-Rodas I, Guidoboni M, McArthur G, Lebbé C, Ascierto PA, Long GV, Cebon J, Sosman J, Postow MA, Callahan MK, Walker D, Rollin L, et al. Overall survival with combined nivolumab and ipilimumab in advanced melanoma. N Engl J Med. 2017;377(14):1345-56

74. Hellmann MD, Rizvi NA, Goldman JW, Gettinger SN, Borghaei H, Brahmer JR, Ready NE, Gerber DE, Chow LQ, Juergens RA, Shepherd FA, Laurie SA, Geese WJ, Agrawal S, Young TC, Li X, Antonia SJ. Nivolumab plus ipilimumab as first-line treatment for advanced non-small-cell lung cancer (CheckMate 012): results of an open-label, phase 1, multicohort study. Lancet Oncol. 18(1):31-41.

75. Rizvi NA, Hellmann MD, Brahmer JR, Juergens RA, Borghaei H, Gettinger S, Chow LQ, Gerber DE, Laurie SA, Goldman JW, Shepherd FA, Chen AC, Shen
Y, Nathan FE, Harbison CT, Antonia S. Nivolumab in combination with platinum-based doublet chemotherapy for first-line treatment of advanced non-small-cell lung cancer. J Clin Oncol. 2016;34(25):2969-79.

76. Langer CJ, Gadgeel SM, Borghaei H, Papadimitrakopoulou VA, Patnaik A Powell SF, Gentzler RD, Martins RG, Stevenson JP, Jalal SI, Panwalkar A, Yang JC, Gubens M, Sequist LV, Awad MM, Fiore J, Ge Y, Raftopoulos $H$, Gandhi L, Investigators K. Carboplatin and pemetrexed with or without pembrolizumab for advanced, non-squamous non-small-cell lung cancer: a randomised, phase 2 cohort of the open-label KEYNOTE021 study. Lancet Oncol. 2016;17(11):1497-508.

77. Wallin JJ, Bendell JC, Funke R, Sznol M, Korski K, Jones S, Hernandez G, Mier J, He X, Hodi FS, Denker M, Leveque V, Canamero M, Babitski G, Koeppen H, Ziai J, Sharma N, Gaire F, Chen DS, Waterkamp D, Hegde PS, McDermott DF. Atezolizumab in combination with bevacizumab enhances antigenspecific T-cell migration in metastatic renal cell carcinoma. Nat Commun. 2016;7:12624.

78. Ahn M-J, Sun J-M, Lee S-H, Ahn JS, Park K, TKI EGFR. Combination with immunotherapy in non-small cell lung cancer. Expert Opin Drug Saf. 2017;16(4):465-9.

79. Gibbons DL, Chow LQ, Kim DW, Kim SW, Yeh T, Song X, Jiang H, Taylor R, Karakunnel J, Creelan B. 570 efficacy, safety and tolerability of MEDI4736 (durvalumab [D]), a human IgG1 anti-programmed cell death-ligand-1 (PD-L1) antibody, combined with gefitinib (G): a phase I expansion in TKI-na\&\#xef;ve patients (pts) with EGFR mutant NSCLC. J Thorac Oncol. 2016;11(4):S79.

80. Ma BBY, Rudin CM, Cervantes A, Dowlati A, Costa D, Schmid P, Heist R, Villaflor VM, Sarkar I, Huseni MA, Foster P, O'Hear C, Gettinger S, Besse B. 4410 preliminary safety and clinical activity of erlotinib plus atezolizumab from a phase lb study in advanced NSCLC. Ann Oncol. 2016;27(suppl_9): mdw594. 005-mdw594.005

81. Vacchelli E, Aranda F, Eggermont A, Sautès-Fridman C, Tartour E, Kennedy EP, Platten M, Zitvogel L, Kroemer G, Galluzzi L. Trial watch: IDO inhibitors in cancer therapy. Oncolmmunology. 2014;3(10):e957994.

82. Zakharia Y, McWilliams R, Shaheen M, Grossman K, Drabick J, Milhem M, Rixie O, Khleif S, Lott R, Kennedy E, Munn D, Vahanian N, Link C. Abstract CT117: interim analysis of the phase 2 clinical trial of the IDO pathway inhibitor indoximod in combination with pembrolizumab for patients with advanced melanoma. Cancer Res. 2017;77(13 Supplement):CT117.

83. Papaemmanuil $E$, Gerstung $M$, Bullinger L, Gaidzik VI, Paschka P, Roberts ND, Potter NE, Heuser M, Thol F, Bolli N, Gundem G, Van Loo P, Martincorena I, Ganly P, Mudie L, McLaren S, O'Meara S, Raine K, Jones DR, Teague JW, Butler AP, Greaves MF, Ganser A, Döhner K, Schlenk RF, Döhner H, Campbell PJ. Genomic classification and prognosis in acute myeloid leukemia. N Engl J Med. 2016;374(23):2209-21.

84. Beaver JA, Tzou A, Blumenthal GM, McKee AE, Kim G, Pazdur R, Philip R, An FDA. Perspective on the regulatory implications of complex signatures to predict response to targeted therapies. Clin Cancer Res. 2017;23(6):1368-72.

85. Philip R, Carrington L, Chan M. US FDA perspective on challenges in codeveloping in vitro companion diagnostics and targeted cancer therapeutics. Bioanalysis. 2011;3(4):383-9.

86. Tsang JY, WL A, Lo KY, Ni YB, Hlaing T, Hu J, Chan SK, Chan KF, Cheung SY, Tse GM. PD-L1 expression and tumor infiltrating PD-1+ lymphocytes associated with outcome in HER2+ breast cancer patients. Breast Cancer Res Treat. 2017;162(1):19-30.

87. Tsao MS, Le Teuff G, Shepherd FA, Landais C, Hainaut P, Filipits M, Pirker R, Le Chevalier T, Graziano S, Kratze R, Soria JC, Pignon JP, Seymour L, Brambilla E. PD-L1 protein expression assessed by immunohistochemistry is neither prognostic nor predictive of benefit from adjuvant chemotherapy in resected non-small cell lung cancer. Ann Oncol. 2017;28:882-9.

88. Tsutsumi S, Saeki H, Nakashima Y, Ito S, Oki E, Morita M, Oda Y, Okano S, Maehara Y. PD-L1 expression at tumor invasive front is associated with EMT and poor prognosis in esophageal squamous cell carcinoma. Cancer Sci. 2017; 118(6):1119-27.

89. Diggs LP, Hsueh EC. Utility of PD-L1 immunohistochemistry assays for predicting PD-1/PD-L1 inhibitor response. Biomarker Res. 2017;5(1):12.

90. Wolchok JD, Hoos A, O'Day S, Weber JS, Hamid O, Lebbe C, Maio M, Binder M, Bohnsack O, Nichol G, Humphrey R, Hodi FS. Guidelines for the evaluation of immune therapy activity in solid tumors: immune-related response criteria. Clin Cancer Res. 2009;15(23):7412-20.

91. Chen Y, Wang Q, Shi B, Xu P, Hu Z, Bai L, Zhang X. Development of a sandwich ELISA for evaluating soluble PD-L1 (CD274) in human sera of 
different ages as well as supernatants of PD-L1+ cell lines. Cytokine. 2011;56(2):231-8.

92. Jeannin P, Magistrelli G, Aubry JP, Caron G, Gauchat JF, Renno T, Herbault N, Goetsch L, Blaecke A, Dietrich PY, Bonnefoy JY, Delneste Y. Soluble CD86 is a costimulatory molecule for human T lymphocytes. Immunity. 2000;13(3):303-12.

93. Oaks MK, Hallett KM. Cutting edge: a soluble form of CTLA-4 in patients with autoimmune thyroid disease. J Immunol. 2000;164(10):5015-8.

94. Oaks MK, Hallett KM, Penwell RT, Stauber EC, Warren SJ, Tector AJ. A native soluble form of CTLA-4. Cell Immunol. 2000;201(2):144-53.

95. Frigola X, Inman BA, Lohse CM, Krco CJ, Cheville JC, Thompson RH, Leibovich B, Blute ML, Dong H, Kwon ED. Identification of a soluble form of $\mathrm{B} 7-\mathrm{H} 1$ that retains immunosuppressive activity and is associated with aggressive renal cell carcinoma. Clin Cancer Res. 2011;17(7):1915-23.

96. Rossille D, Gressier M, Damotte D, Maucort-Boulch D, Pangault C, Semana G, Le Gouill S, Haioun C, Tarte K, Lamy T, Milpied N, Fest T, Groupe Ouest-Est des Leucemies et Autres Maladies du S, Groupe Ouest-Est des Leucemies et Autres Maladies du S. High level of soluble programmed cell death ligand 1 in blood impacts overall survival in aggressive diffuse large B-cell lymphoma: results from a French multicenter clinical trial. Leukemia. 2014;28(12):2367-75.

97. Zhang J, Gao J, Li Y, Nie J, Dai L, Hu W, Chen X, Han J, Ma X, Tian G, Wu D, Shen L, Fang J. Circulating PD-L1 in NSCLC patients and the correlation between the level of PD-L1 expression and the clinical characteristics. Thorac Cancer. 2015;6(4):534-8

98. Okuma Y, Hosomi Y, Nakahara Y, Watanabe K, Sagawa Y, Homma S. High plasma levels of soluble programmed cell death ligand 1 are prognostic for reduced survival in advanced lung cancer. Lung Cancer. 2017;104:1-6.

99. Zhou Q, Yang J-J, Chen Z-H, Zhang X-C, Yan H-H, C-R X, Su J, Chen H-J, H-Y T, Zhong W-Z, Yang $X-N, Y-L$ W. Serial cfDNA assessment of response and resistance to EGFR-TKI for patients with EGFR-L858R mutant lung cancer from a prospective clinical trial. J Hematol Oncol. 2016;9:86.

100. Chong EA, Melenhorst JJ, Lacey SF, Ambrose DE, Gonzalez V, Levine BL, June $\mathrm{CH}$, Schuster SJ. PD-1 blockade modulates chimeric antigen receptor (CAR)-modified T cells: refueling the CAR. Blood. 2017;129(8):1039-41.

101. Maude SL, Hucks GE, Seif AE, Talekar MK, Teachey DT, Baniewicz D, Callahan C, Gonzalez V, Nazimuddin F, Gupta M, Frey NV, Porter DL, Levine BL, Melenhorst JJ, Lacey SF, June CH, Grupp SA. The effect of pembrolizumab in combination with CD19-targeted chimeric antigen receptor (CAR) T cells in relapsed acute lymphoblastic leukemia (ALL). J Clin Oncol. 2017;35(15_suppl):103.

\section{Submit your next manuscript to BioMed Central and we will help you at every step:}

- We accept pre-submission inquiries

- Our selector tool helps you to find the most relevant journal

- We provide round the clock customer support

- Convenient online submission

- Thorough peer review

- Inclusion in PubMed and all major indexing services

- Maximum visibility for your research

Submit your manuscript at www.biomedcentral.com/submit
Biomed Central 